\title{
Forecasting coal production until 2100
}

\author{
S. H. Mohr ${ }^{a, *}$ G. M. Evans ${ }^{a}$ \\ ${ }^{a}$ University of Newcastle, Faculty of Engineering and Built Environment, Chemical \\ Engineering, University Drive, Callaghan, NSW 2308, Australia
}

\begin{abstract}
A model capable of projecting mineral resources production has been developed. The model includes supply and demand interactions, and has been applied to all coal producing countries. A model of worldwide coal production has been developed for three scenarios. The ultimately recoverable resources (URR) estimates used in the scenarios ranged from $700 \mathrm{Gt}$ to $1243 \mathrm{Gt}$. The model indicates that worldwide coal production will peak between 2010 and 2048 on a mass basis and between 2011 and 2047 on an energy basis. The Best Guess scenario, assumed a URR of 1144 Gt and peaks in 2034 on a mass basis, and in 2026 on an energy basis.
\end{abstract}

Key words:

Coal reserves, Peak coal, Coal production

\section{Introduction}

Coal is widely used in the generation of electricity and in the production of steel, and is considered to be an abundant resource. In 2006 World production of all coal

* Corresponding author.

Email addresses: steve.mohrestudentmail . newcastle.edu.au (S. H. Mohr), Geoffrey.Evans@newcastle.edu.au (G. M. Evans). 
types was $6.2 \mathrm{Gt} / \mathrm{y}$ and the current reserves to production ratio $(\mathrm{R} / \mathrm{P})$ is 133 years [1]. There have been a few estimates of future coal production and all [2-4] have used Hubbert's bell curve technique. Hubbert [2] in 1976 estimated future coal production by applying a bell shaped curve to global production, and predicted it would peak at between 10 and $24 \mathrm{Gt} / \mathrm{y}$ in 2100-2200 depending on the URR. Laherrere [3] in 2004 used a similar approach to obtain a peak production of $\sim 7.2 \mathrm{Gt} / \mathrm{y}$ in 2050. The EWG [4] in 2007 used a modified approach, in that future production was assumed to be a bell shaped production profile was applied to all countries and types, rather than on a global basis and only applied the profile to recent production statistics to obtain a peak production of $\sim 7.4 \mathrm{Gt} / \mathrm{y}$ in 2025 . The notion that coal is abundant is less clear, whilst the R/P ratio and early literature[2] indicates coal is abundant[1], recent studies[3,4] suggest otherwise.

The reduction in the peak year estimates from Hubbert [2] (2100-2200) to the most recent analysis from the EWG [4] (2025) highlight important differences in the modelling analysis. Firstly, the discrepancy in the predictions between Hubbert [2] and Laherrere [3] (2050) is due to a lower URR value assumed by Laherrere [3]; both modelled production as a bell curve and applied it to global coal production. Secondly, while Laherrere [3] and EWG [4] assumed much the same URR, ${ }^{a}$, Laherrere modelled production globally, while EWG considered individually each country and coal type. It is not clear why the two studies, using similar analysis, should produce a 25 year difference in peak production.

The differences in peak coal production year estimates raises a number of questions about the overall modelling approach to coal production; especially given that the most recent prediction[4] forecasts that coal production will decline beyond 2025 .

a Laherrere[3] assumes a URR of 600 Gtoe, and the EWG[4] assume cumulative production plus reserves, obtained from WEC 2007 [5] with the exception of USA. On a tonnes basis both equate to a URR of $\sim 1100-1200 \mathrm{Gt}$ 
The aim of this study therefore, was to critically examine URR estimates and to develop a coal production model based on a country-by-country analysis, which is not reliant on a bell curve production profile. The resultant peak year prediction could then be compared to the previous studies.

A review of literature will be presented to determine the coal ultimately recoverable resources (URR) estimates. The URR for a region is for the purpose of this article assumed to be the total amount of coal the region extracts from the earth over a time scale of roughly the past 250 years to the next 1000 years. Peat and oil shale will not be considered as coal; the data will be split as best as possible into Anthracite, Bituminous, Sub-bituminous and Lignite for each country which had or has coal. A description of the model developed to predict coal production will be provided. The results of the model along with a discussion will be presented, followed by a conclusion.

\section{Literature ultimately recoverable resources estimates}

There are very few URR estimates for coal, Hubbert [2] assumed in 1976 that the coal URR was between 2,000 Gt and 7,600 Gt. Ion [6] in 1975 estimated remaining minable coal resource at 4,640 Gt; corresponding to a URR of $\sim 4,800 \mathrm{Gt}$. Laherrere [3] in 2004 and EWG [4] both assumed a coal URR of 1100-1200 Gt. In the case of the EWG [4], the URR was determined by assuming that WEC 2007 [5] reserve values combined with cumulative production represented the best estimate of the URR. Rutledge [7] estimated the worldwide coal URR to be approximately $660 \mathrm{Gt}$, using only coal production statistics and the technique of Hubbert Linearisation.

The EWG [4] consider their URR value as an overestimate of the actual URR, whereas others believe it would be an underestimate [8]. The conventional view is 
that the URR estimate from the EWG [4] would be too low as Thielemann et al [8] explains "Every year, coal resources move into reserves as our knowledge of coal deposits improve and new pits or pit sections are developed". So by the conventional view we would expect the URR from EWG [4] and Laherrere [3] to be an underestimate. However the EWG [4] and Kavalov [9] both highlight that reserve and resource estimates have been declining. Resources have decreased nearly $50 \%$ over the last 25 years [4] and reserves have decreased by 137 Gt during the last 6 years to now be $847 \mathrm{Gt}$ [9]. However the conventional theory indicates that reserves and resources should have increased [8]. Ultimately since coal resources and reserves have not been following the conventional view we can only assume that the EWG [4] URR estimate is an overestimate.

Three scenarios are analysed in the article. In the first scenario we estimated worldwide coal URR based on Hubbert's Linearisation technique (denote this scenario HL) and applied the method to all countries with coal production. ${ }^{\mathrm{b}}$. We obtained a URR of $700 \mathrm{Gt}$ from the Hubbert Linearisation technique, ${ }^{\mathrm{c}}$ which is very similar to Rutledge's estimate of $660 \mathrm{Gt}$, using the same technique [7]. The second scenario calculated the URR via the method of adding reserves to cumulative production and this scenario is denoted $\mathrm{R}+\mathrm{C}$. We estimated a URR of $1243 \mathrm{Gt}$ by the $\mathrm{R}+\mathrm{C}$ method, which is similar to the EWG[4] and Laherrere [3] URR value. The last scenario is our Best Guess estimate of the URR. The Best Guess scenario, denoted BG, assumes a URR of 1144 Gt. Table B.1 indicates the URR for all countries and types, and details where the URR values are determined.

$\overline{\mathrm{b}}$ Coal production statistics used in this article were estimated from a variety of sources $[1,5,7,10-21]$ The coal production statistics used have been placed in the electronic supplement to this article.

$c$ see Appendix C 


\section{Model description}

The model has been briefly described previously [22] and will be explained in detail here. The modelling philosophy was to try and replicate real World exploitation of a mineral resource. The model includes supply and demand interactions so that production is influenced by the demand. The model has production occurring from individual mines, and production can be increased by bringing more mines online or upgrading existing mines. Outside influences such as wars and depressions can also be factored into the model. The model has several key steps:

(1) The markets to which the model interacts with is chosen. In the three scenarios for the coal model, the markets chosen are regional/continental and are: Africa, Asia, FSU, Europe, North America, Oceania, and South America.

(2) The model works on individual countries and types. For each country and type, the maximum production of all mines, $M_{P}^{j}$ is estimated along with the mine-life of all mines $M_{L}^{j}$. All mines are assumed to take 4 years to start up and shut down, along with the ability to have a forced shutdown early and restart later on. There is also the ability for mines to upgrade, which involves a mine increasing production over 4 years to twice the maximum production for the rest of its working life. $M_{L}^{j}$ and $M_{P}^{j}$ combined with the individual URR, determines the total number of mines $M_{T}^{j}$ for the country and type. Figure 1 shows an illustrative example of an individual mine's production.

(3) An iterative procedure is applied, which has supply and demand interactions applied on a continent level. The iterative procedure determines when mines come online, if they have a forced shutdown, and if/when they upgrade. Production for the country is readily determined by adding the production from the individual mines. 
The iterative procedure is explained in some detail here. The model examined each market (Asia, Europe, etc) separately, and for each year the total number of the individual mines' production is added to obtain a production total for each country and type. For example, assume that we are at year $t$ and in a particular continent and we know the following terms: the intrinsic demand in year $t, M_{D}[t]$, and the total supply for a continent at year $t, M_{S}[t]$. Also for each country and type in the continent we know the amount of coal produced in year $t, P^{j}[t]$, and the number of mines online, $M^{j}[t]$, and the activities of the mines (commenced, shut down, upgraded). We now need to determine the supply and demand for the year $t+1$.

\subsection{Demand}

The demand $M_{D}[t+1]$ for the continent is estimated by equation 1 .

$$
M_{D}[t+1]=M_{D}[t] e^{k_{D}[t]}, \text { where, } M_{D}[0]=M_{D 0}
$$

where $M_{D 0}$ is the initial demand, and $k_{D}[t]$ is the demand rate variable, which is described in equation 2

$$
k_{D}[t]=k_{D 0}-k_{1}\left(\frac{M_{S}[t]-M_{D}[t]}{M_{S}[t]}\right) .
$$

where $k_{D 0}$ is the equilibrium growth rate value, and $k_{1}$ is a proportionate constant linking the difference in supply and demand to the demand growth rate. $k_{D 0}$ ranged from 0.035 to 0.1 in value and all except for Asia are constant. In Asia $k_{D 0}$ changed from 0.05 to 0.10 in order to account for the rapid development in China and India since the Asian Crisis in 1999. 


\subsection{Supply}

The supply of coal in the year $t+1, M_{S}[t+1]$, is determined by summing the productions in the individual countries and coal types in the year $t+1, P^{j}[t+1]$ as shown in equation 3.

$$
M_{S}[t+1]=\sum_{j} P^{j}[t+1]
$$

The production of coal in a given country and type, $P^{j}[t+1]$, is determined by knowing whether or not there is a disruption in year $t$. A disruption is added into the model to take account of effects such as the Great Depression and World wars etc. If a disruption has been inputted into the model, then some of the mines are brought offline, and hence production is reduced. If no disruption is present, then the number of new mines brought online or restarted needs to be determined.

The number of mines online $M^{j}[t+1]$ is a function of production, $P^{j}[t]$, and of the supply and demand as shown in equation 4.

$$
M^{j}[t+1]=\left\lceil M_{T}^{j}-\left(M_{T}^{j}-M^{j}[t]\right) e^{\left.-k_{S}^{j}[t] \frac{P^{j}[t]}{U R R^{j}}\right\rceil}\right.
$$

where $k_{S}^{j}[t]$ is the supply rate variable for the specific country and type, note that initially one mine is online. The supply rate variable is similar to the demand rate variable and is shown in equation 5

$$
k_{S}^{j}[t]=k_{S 0}^{j}+k_{2}\left(\frac{M_{S}[t]-M_{D}[t]}{M_{S}[t]}\right)
$$

where $k_{S 0}^{j}$ is the equilibrium supply rate for the specific country and type and $k_{2}$ is a 
proportionate constant applied to all countries and regions. The equilibrium supply rate is a constant in almost all cases. However, in a few key places, events have caused this value to have a step change: In North America, at the end of the 1960's there was a strong departure from high sulfur USA bituminous coals to lower sulfur coals and this had the effect of stunting USA bituminous coal production, whilst also heavily increasing production from other coal sources. The second place where $k_{S 0}$ is not a constant is in China, where the rate of growth since 2000 has been considerably higher than was previously the case.

The last component of the iterative procedure is determining how many mines are upgraded each year. The number of mines upgraded between year $t$ and $t+1$, $M_{U}^{j}[t+1]$, is determined by equation 6 , and is directly related to the number of mines online and the difference between supply and demand.

$$
M_{U}^{j}[t+1]=\left\lceil k_{3}\left(\frac{M_{S}[t]-M_{D}[t]}{M_{S}[t]}-k_{U}\right) M^{j}[t]\right\rceil
$$

where $k_{U}$ is a minimum gap between supply and demand necessary before mines are upgraded, and $k_{3}$ is a proportionality constant. Let $q^{j i}[t+1]$ denote the production $i$-th mine in the $j$-th country and type in the year $t+1$. Since we know when the $i$-th mine started and its history, we can determine the total supply to the market as:

$$
\begin{aligned}
M_{S}[t+1] & =\sum_{j} P^{j}[t+1] \\
& =\sum_{j} \sum_{i=1}^{M^{j}[t+1]} q^{j i}[t+1]
\end{aligned}
$$

The constants $k_{1}, k_{2}, k_{3}, k_{U}$ are on a continent basis.

Historically, Europe is the only continent where coal production has already peaked 
and is declining; Europe peaked in 1988 and production is declining at an average rate of $3 \%$ per year. The constants were determined by finding the best fit to European production and these values were then used for the other continents and scenarios, all of which have not peaked. The constant $k_{S 0}$ is determined by fitting to the individual production curve for a given country and type. The constant $k_{D 0}$ is determined, by observing the historical growth rate for each continent.

\section{Results and discussion}

The model's predictions of coal production are shown in three formats. Figure 2 shows production from the major coal producing countries on a tonnage basis, Figure 3 indicates the production of the different coal types, in tonnes, and Figure 4 has the coal production by coal type in energy units (EJ). The model indicates World coal production in tonnes will peak between 2010 and 2048, and in an energy basis, will peak between 2011 and 2047. The large range in peak year estimates cannot be narrowed until reliable URR estimates are available.

In the analysis it is assumed that the HL trend provides a good estimation of the URR of a given country, noting however, if production is declining rapidly the HL trend will over-estimate the URR, while for minimal or non-existent production the HL trend will under-estimate the URR. The $\mathrm{R}+\mathrm{C}$ scenario URR is assumed to be an overestimate due to the declining official reserves and resources [4,9], which are speculated to continue to decline[4]. We therefore cautiously believe that the worldwide coal URR is between 700 and $1243 \mathrm{Gt}$, and that the prediction from the model implies that coal production will peak sometime between 2010 and 2048, is approximately correct. Our BG scenario URR of $1144 \mathrm{Gt}$ is a slightly educated guess, and is typically obtained by choosing the $\mathrm{HL}$ or $\mathrm{R}+\mathrm{C}$ scenario URR values 
for each different country and type. The BG scenario indicates that coal production will peak in 2034 on a tonnage basis and in 2026 on an energy basis. Based on the coal URR estimates, the notion that coal is abundant is unlikely, however further work is needed to determine accurate URR estimates.

\subsection{Model criticism}

The model has numerous limitations which will be outlined. The model required more than 400 constants to be inputted, $\left(M_{L}^{j}, M_{P}^{j}\right.$ and $k_{S 0}^{j}$ for all 132 countries and type, as well as $\left.k_{U}, k_{1}, k_{2}, k_{3}\right)$. The number of constants makes application of the model difficult and time consuming. The assumption that all the maximum mine productions for a given country and type is constant over time is too simplistic, as history indicates maximum mine production rates increased over time in America [24]. The iterative approach of the model causes the model to take several hours to run. It is preferred that external disruptions such as the Great Depression be implemented in demand rather than supply. Laherrere [3] and the EWG [4] using Hubbert's Theory and a similar URR, produce moderately similar peak year estimates, hence there are questions as to why develop such a complicated model.

There were numerous reasons for why the model was created. First, Hubbert's theory assumes production is a symmetric bell curve, yet analysis similar to that done by Brandt [23] for oil production, indicates that the rate difference $\Delta r=r_{i n c}-r_{d e c}$ is negative with a mean of -0.019 and a median of -0.018 , with a standard deviation of 0.059 (see Appendix for more details). Also with Hubbert's method there is no underlying theory explaining why production ought to follow a symmetric bell curve. Our model has been developed to attempt to replicate how coal is extracted with production from mines and with supply and demand interactions, as well as external disruptions (wars, depressions, etc). The number of constants re- 
quired is time consuming, and work is continuing to develop a normalised approach to readily apply the model to many countries, which could minimise the number of variables used. Further work is required to produce better models that are more effective and replicate reality more accurately.

\section{Conclusion}

A model has been developed which uses supply and demand considerations and this has been used to model worldwide coal production. The model has been applied to coal, but can be used for any resource where production is derived from mining. World coal URR value has been estimated at between 700 and $1243 \mathrm{Gt}$ of coal. The model projects that worldwide coal production will peak between 2010 and 2048 on a tonnage basis, and between 2011 and 2047 on an energy basis. The notion that coal is widely abundant therefore appears to be unjustified. Further work is needed to better determine the URR range of coal.

\section{Acknowledgment}

Steve Mohr wishes to thank the Centre for Sustainable Resource Processing for funding. We wish to thank the EIA, and Minerals UK staff as well as Jean Laherrere and Dave Rutledge for their help in acquiring coal production statistics. Thanks too, to Michelle Buckland for her assistance in the preparation of the final manuscript. 


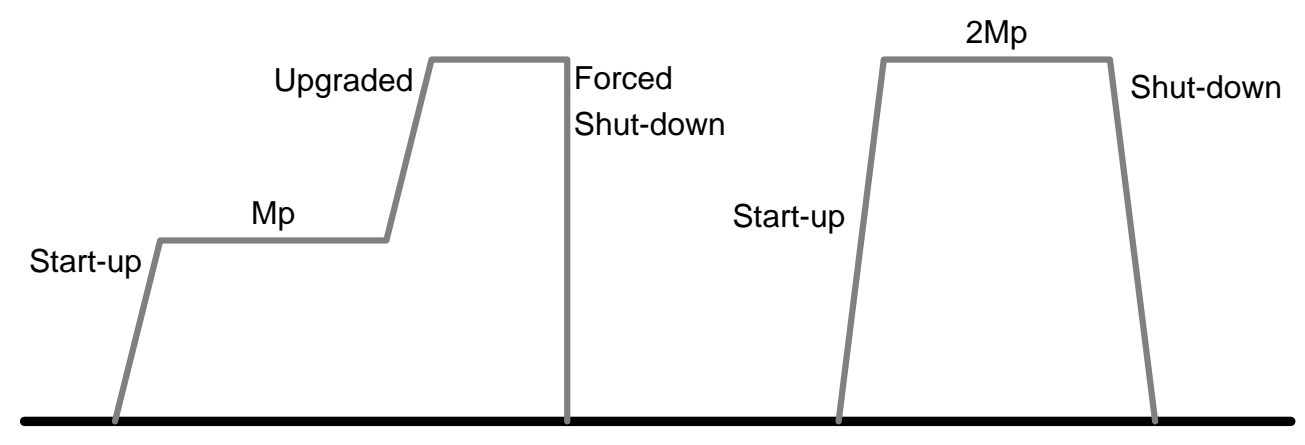

Fig. 1. An example of a mines production over time 
(a)

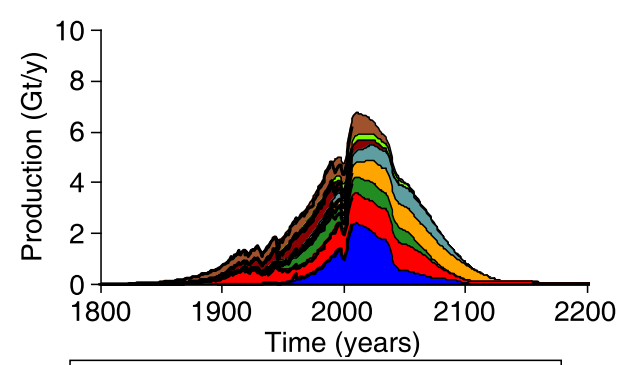

(b)

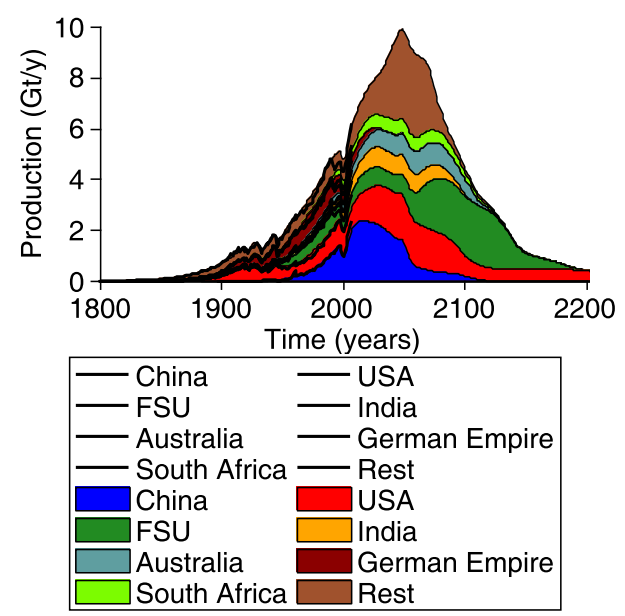

(c)

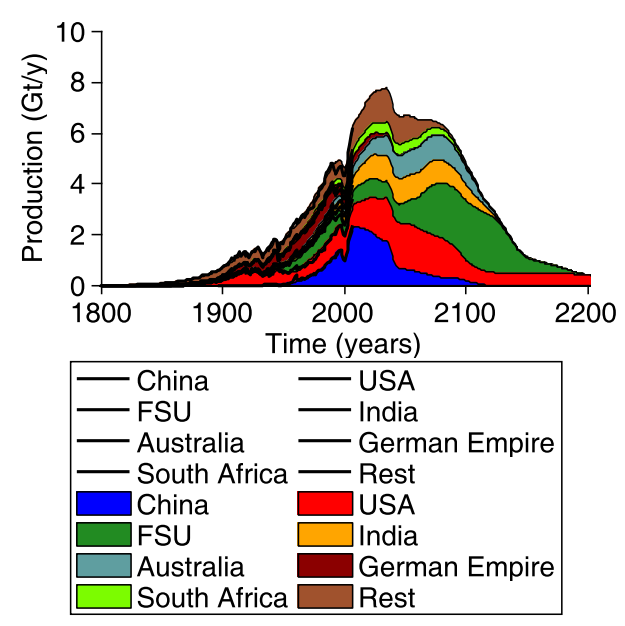

Fig. 2. Coal production prediction for major producers in Gt/y for a) The HL scenario b) The $\mathrm{R}+\mathrm{C}$ scenario c) The $\mathrm{BG}$ scenario 
(a)
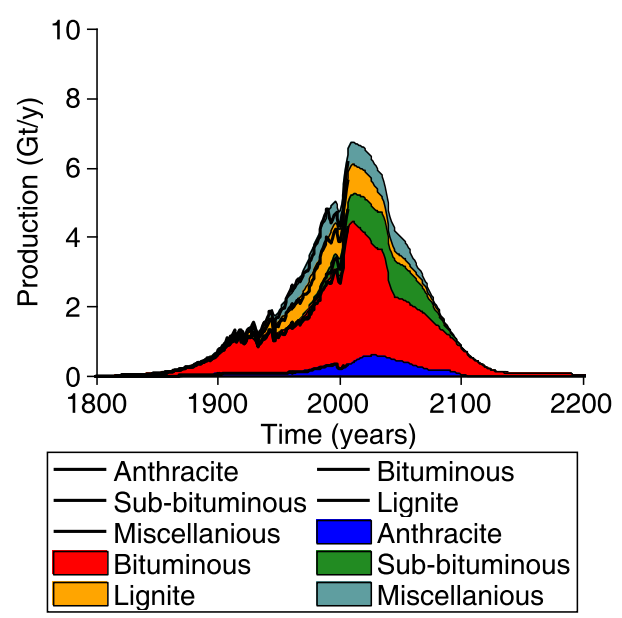

(b)
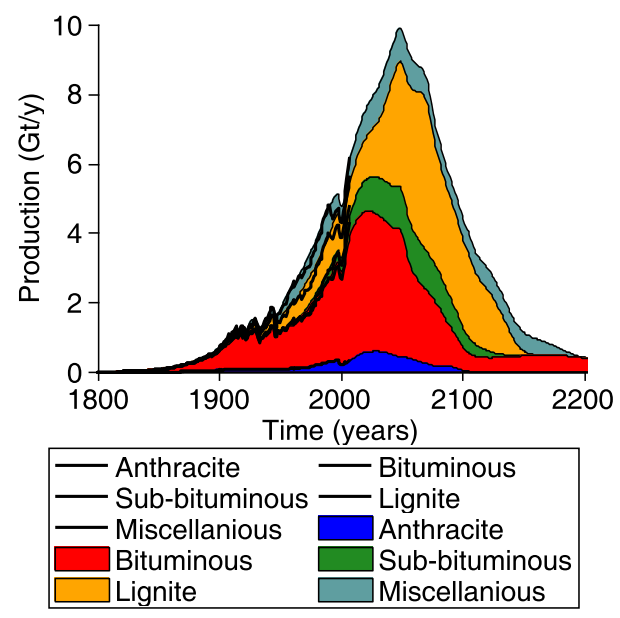

(c)

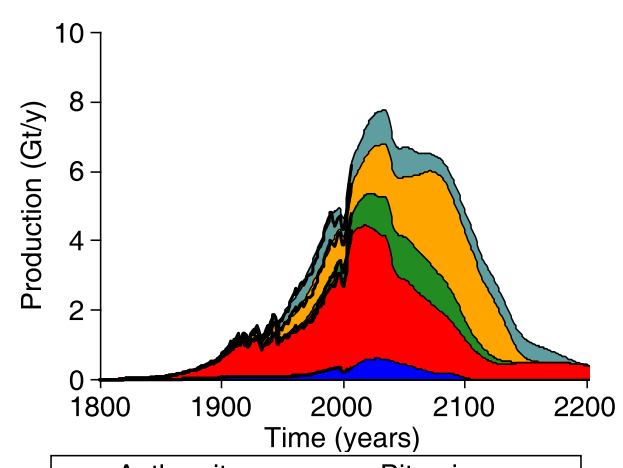

\begin{tabular}{|ll|}
\hline Anthracite & Bituminous \\
Sub-bituminous & Lignite \\
Miscellanious & Anthracite \\
\hline Bituminous & Sub-bituminous \\
\hline Lignite & Miscellanious \\
\hline
\end{tabular}

Fig. 3. Coal production prediction for different coal types in Gt/y for a) The HL scenario b) The $\mathrm{R}+\mathrm{C}$ scenario c) The $\mathrm{BG}$ scenario 
(a)

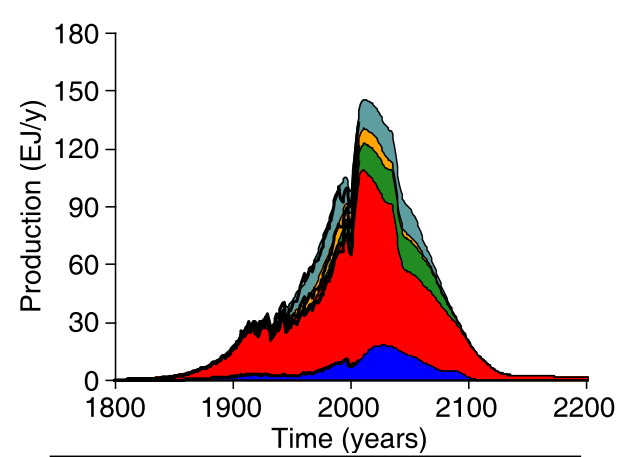

(b)
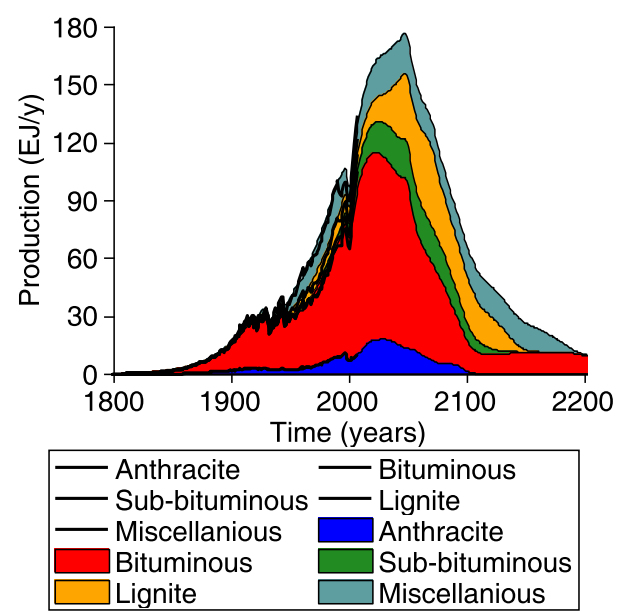

(c)

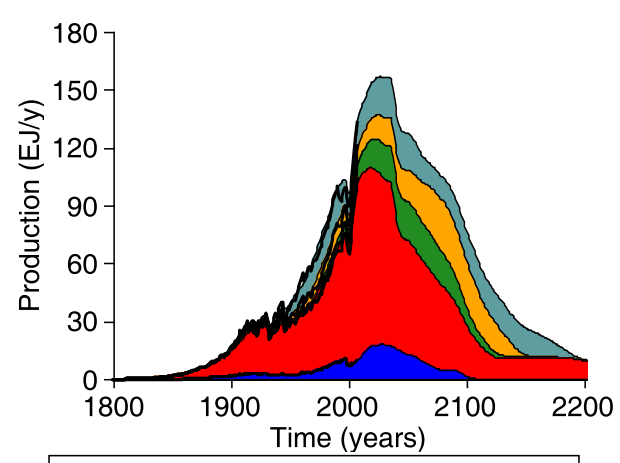

\begin{tabular}{|ll|}
\hline Anthracite & Bituminous \\
Sub-bituminous & Lignite \\
Miscellanious & Anthracite \\
\hline Bituminous & Sub-bituminous \\
\hline Lignite & Miscellanious \\
\hline
\end{tabular}

Fig. 4. Coal production prediction for different coal types in EJ/y for a) The HL scenario b) The $\mathrm{R}+\mathrm{C}$ scenario c) The BG scenario 
(a)

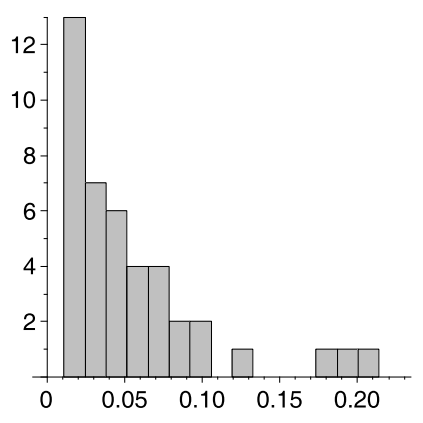

(b)

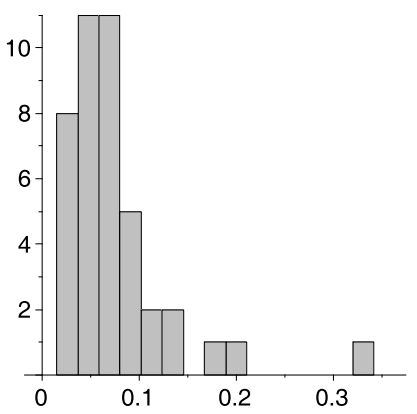

(c)

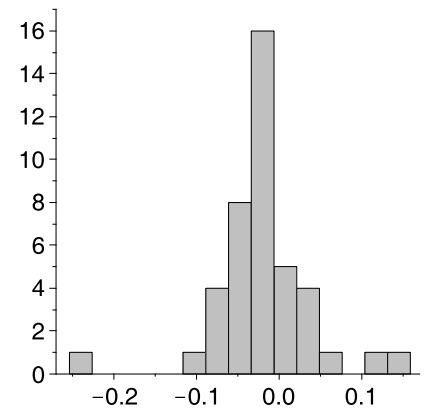

Fig. A.1. Histogram for exponential model fitted to coal producing countries that have peaked a) $r_{i n c}$ b) $r_{d e c}$ c) $\Delta r$

\section{A Coal data analysis}

The exponential functions applied to the coal producing countries that have peaked, were:

$$
\begin{aligned}
& y(t)=y_{p 1} e^{r_{i n c}\left(t-t_{p 1}\right)} ; t \leq t_{p 1} \\
& y(t)=y_{p 2} e^{r_{d e c}\left(t-t_{p 2}\right)} ; t \geq t_{p 2}
\end{aligned}
$$

where, $\left(t_{p 1}, y_{p 1}\right)$ is the point where production enters the plateau of production, and $\left(t_{p 2}, y_{p 2}\right)$ is the point where production exits the production plateau. The histograms of $r_{i n c}, r_{d e c}$ and $\Delta r$ are shown in Figure A.1

\section{B Tabulated results}


Table B.1

The URR estimates for the different scenarios in Gt

\begin{tabular}{|c|c|c|c|c|c|c|c|c|c|c|}
\hline & \multirow{2}{*}{ Country } & \multirow{2}{*}{ Type $^{a}$} & \multicolumn{3}{|c|}{ URR } & \multirow{2}{*}{ Country } & \multirow{2}{*}{ Type $^{a}$} & \multicolumn{3}{|c|}{ URR } \\
\hline & & & $\mathrm{HL}^{\mathrm{b}}$ & $\mathrm{R}+\mathrm{C}^{\mathrm{c}}$ & $\mathrm{BG}^{\mathrm{d}}$ & & & $\mathrm{HL}^{\mathrm{b}}$ & $\mathrm{R}+\mathrm{C}^{\mathrm{c}}$ & $\mathrm{BG}^{\mathrm{d}}$ \\
\hline \multirow{4}{*}{ 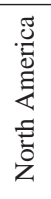 } & & Bit & 2.4 & 5.2 & 2.4 & \multirow{4}{*}{ USA } & Ant & 5.1 & 5.1 & 5.1 \\
\hline & Canada & Sub & 1.4 & 1.7 & 1.7 & & Bit & 87.3 & 161.6 & 161.6 \\
\hline & & Lig & 0.7 & 2.6 & 0.7 & & Sub & 74.5 & 108.7 & 108.7 \\
\hline & Mexico & Bit & 0.6 & 1.6 & 1.6 & & Lig & 4.8 & 32.7 & 32.7 \\
\hline \multirow{5}{*}{ 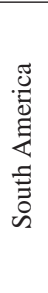 } & Argentina & Bit & - & 0.4 & $0.1^{\mathrm{e}}$ & Columbia & Bit & 3.5 & 7.8 & 7.8 \\
\hline & Bolivia & Bit & 0 & - & - & Ecuador & Lig & 0 & - & - \\
\hline & Brazil & Bit & 0.3 & 3.7 & 3.7 & Peru & Ant & - & 0.1 & 0.1 \\
\hline & & Lig & 0.2 & 3.6 & 3.6 & & Bit & - & - & - \\
\hline & Chile & $\begin{array}{l}\text { Bit } \\
\text { Lig }\end{array}$ & $\begin{array}{l}0.1 \\
-\end{array}$ & $\begin{array}{l}0.2 \\
1.2\end{array}$ & $\begin{array}{l}0.1 \\
1.2\end{array}$ & Venezuela & Bit & 0.2 & 0.6 & 0.6 \\
\hline \multirow{11}{*}{$\stackrel{\frac{\pi}{3}}{\&}$} & \multirow{2}{*}{ Algeria } & Bit & - & 0.1 & - & Niger & Bit & - & 0.1 & 0.1 \\
\hline & & Lig & - & - & - & Nigeria & Sub & - & 0.2 & - \\
\hline & Botswana & Bit & - & 0.1 & 0.1 & \multirow{2}{*}{ South Africa } & Ant & 0.2 & 0.2 & 0.2 \\
\hline & C. A. R. & Lig & 0 & - & - & & Bit & 18.0 & 55.1 & $38.7^{\mathrm{e}}$ \\
\hline & Cameroon & Bit & - & - & - & Swaziland & Bla & - & 0.2 & 0.2 \\
\hline & Egypt & Bit & - & - & - & Tanzania & Bit & - & 0.2 & 0.2 \\
\hline & Eritrea & Lit & - & - & - & \multirow{2}{*}{ Tunisia } & Sub & - & - & - \\
\hline & Malawi & Sub & - & - & - & & Lig & - & - & - \\
\hline & Madagascar & Bit & - & - & - & Zaire & Bit & - & 0.1 & 0.1 \\
\hline & Morocco & Ant & - & - & - & Zambia & Bit & - & - & - \\
\hline & Mozambique & Bit & - & 0.2 & - & Zimbabwe & Bit & 0.4 & 0.7 & 0.4 \\
\hline \multirow{4}{*}{ 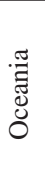 } & & Bit & 51.3 & 43.3 & 51.3 & \multirow{4}{*}{ N.Z. ${ }^{f}$} & Ant & - & - & - \\
\hline & Australia & Sub & 3.2 & 2.7 & 3.2 & & Bit & 0.4 & 0.1 & 0.4 \\
\hline & & Lig & 8.2 & 39.5 & 39.5 & & Sub & 0.9 & 0.4 & 0.9 \\
\hline & N.C. & Ant & - & - & - & & Lig & 0.1 & 0.4 & 0.1 \\
\hline \multirow{18}{*}{. $\frac{\pi}{4}$} & Afghanistan & Bit & - & 0.1 & 0.1 & \multirow{2}{*}{$\begin{array}{l}\text { Korean } \\
\text { Peninsula }\end{array}$} & Ant & 2.1 & 2.2 & 2.2 \\
\hline & Bangladesh & Bit & - & $2.5^{\mathrm{g}}$ & $0.3^{\mathrm{h}}$ & & Lig & 0.4 & 0.8 & $0.8^{\mathrm{k}}$ \\
\hline & Bhutan & Bit & - & - & - & Laos & Bit & - & - & - \\
\hline & Brunei & Unk & - & - & - & Lebanon & Lig & - & - & - \\
\hline & \multirow{2}{*}{ Burma } & Bit & - & - & - & Malaysia & Sub & - & - & - \\
\hline & & Lig & $-{ }^{\mathrm{i}}$ & - & - & \multirow{2}{*}{ Mongolia } & Bit & 0.1 & $13.6^{\ell}$ & $2^{\mathrm{m}}$ \\
\hline & \multirow{3}{*}{ China } & Ant & 38.3 & 38.3 & 38.3 & & Lig & 0.3 & $86.6^{\ell}$ & $13.2^{\mathrm{m}}$ \\
\hline & & Bit & 80.6 & 98.2 & $78.4^{\mathrm{j}}$ & Nepal & Sub & - & - & - \\
\hline & & Lig & 9.0 & 20.2 & $19.4^{\mathrm{j}}$ & Pakistan & Bro & 0.2 & 2.1 & 2.1 \\
\hline & India & Bit & 94.2 & 61.9 & $99.7^{\mathrm{k}}$ & Philippines & BSB & - & 0.4 & $0.4^{\mathrm{e}}$ \\
\hline & & Lig & 3.2 & 4.8 & 4.8 & Taiwan & Bit & 0.2 & 0.2 & 0.2 \\
\hline & Indonesia & Ant & - & - & - & & Ant & - & - & - \\
\hline & Hiventa & Bit & 4.2 & 5.6 & 5.6 & Thailand & Bit & - & - & - \\
\hline & Iran & Bit & 0.1 & 1.4 & $0.5^{\mathrm{k}}$ & & Lig & 0.8 & 1.7 & 0.8 \\
\hline & & Ant & 0.1 & 0.1 & 0.1 & & Ant & $4.4^{\mathrm{i}}$ & $4.4^{n}$ & 4.4 \\
\hline & Japan & Bit & 2.9 & 3.2 & 2.9 & Vietnam & Bit & - & - & - \\
\hline & & & & & & & Sub & - & - & - \\
\hline & & Lig & - & - & - & & Lig & - & - & - \\
\hline
\end{tabular}


Table B.1 Continued

\begin{tabular}{|c|c|c|c|c|c|c|c|c|c|c|}
\hline & \multirow{2}{*}{ Country } & \multirow{2}{*}{ Type $^{\mathrm{a}}$} & \multicolumn{3}{|c|}{ URR } & \multirow{2}{*}{ Country } & \multirow{2}{*}{ Type $^{\mathrm{a}}$} & \multicolumn{3}{|c|}{ URR } \\
\hline & & & $\mathrm{HL}^{\mathrm{b}}$ & $\mathrm{R}+\mathrm{C}^{\mathrm{c}}$ & $\mathrm{BG}^{\mathrm{d}}$ & & & $\mathrm{HL}^{\mathrm{b}}$ & $\mathrm{R}+\mathrm{C}^{\mathrm{c}}$ & $\mathrm{BG}^{\mathrm{d}}$ \\
\hline \multirow{22}{*}{ 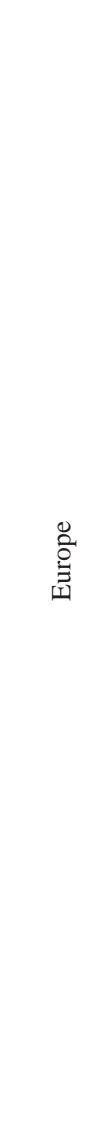 } & Albania & Lig & - & 0.8 & - & Northern & Bit & - & - & - \\
\hline & AustroHungarian & Bit & 2.7 & 4.4 & 2.7 & Ireland & Lig & - & - & - \\
\hline & Empire & Bro & 8.5 & 13.5 & 8.5 & Norway & Bit & 0.1 & - & 0.1 \\
\hline & Polaium & Ant & 0.7 & 0.7 & 0.7 & \multirow{3}{*}{ Portugal } & Ant & - & - & - \\
\hline & DetgiunI & Bit & 1.9 & 1.9 & 1.9 & & Bit & - & - & - \\
\hline & \multirow{3}{*}{ Bulgaria } & Ant & - & - & - & & Bro & - & - & - \\
\hline & & Bit & - & - & - & \multirow{3}{*}{ Romania } & Bit & 0.4 & 0.4 & 0.4 \\
\hline & & Lig & 2.1 & 3.5 & 2.1 & & Sub & 0.1 & 0.1 & 0.1 \\
\hline & Denmark & Lig & 0.1 & 0.1 & 0.1 & & Lig & 1.6 & 1.6 & 1.6 \\
\hline & \multirow{2}{*}{ France } & Bit & 4.4 & 4.4 & 4.4 & \multirow{3}{*}{ Spain } & Ant & 0.3 & 0.3 & 0.3 \\
\hline & & Lig & 0.2 & 0.2 & 0.2 & & BSB & 1.0 & 1.4 & 1.0 \\
\hline & \multirow{3}{*}{$\begin{array}{l}\text { German } \\
\text { Empire }\end{array}$} & Ant & 0.6 & 0.6 & 0.6 & & Lig & 0.6 & 0.5 & 0.6 \\
\hline & & Bit & 25.2 & 29.1 & 25.2 & Sweden & Bit & - & - & - \\
\hline & & Lig & 32.1 & 34.8 & $32.2^{\circ}$ & \multirow{2}{*}{ Switzerland } & Bit & - & - & - \\
\hline & Greece & Lig & 3.7 & 5.5 & 5.5 & & Bro & - & - & - \\
\hline & Greenland & Bit & - & 0.2 & - & \multirow{3}{*}{ Turkey } & Ant & - & - & - \\
\hline & \multirow{2}{*}{ Ireland } & Ant & - & - & - & & Bit & 0.4 & $0.6^{\mathrm{k}}$ & $0.6^{\mathrm{k}}$ \\
\hline & & SBi & - & - & - & & Lig & 1.9 & 3.1 & $5.2^{\mathrm{k}}$ \\
\hline & \multirow{3}{*}{ Italy } & Ant & - & - & - & \multirow{3}{*}{ UK } & Ant & 0.6 & 0.6 & 0.6 \\
\hline & & Bit & - & - & - & & Bit & 26.8 & 26.7 & 26.8 \\
\hline & & Bro & 0.1 & 0.1 & 0.1 & & Lig & - & - & - \\
\hline & Netherlands & $\begin{array}{l}\text { Bla } \\
\text { Bro }\end{array}$ & $\begin{array}{l}0.6 \\
-\end{array}$ & $\begin{array}{l}0.6 \\
-\end{array}$ & $\begin{array}{l}0.6 \\
-\end{array}$ & Yugoslavia & $\begin{array}{l}\text { Bit } \\
\text { Bro }\end{array}$ & $\begin{array}{l}- \\
4.7\end{array}$ & $\begin{array}{l}0.1 \\
16.7\end{array}$ & $\begin{array}{l}- \\
16.7\end{array}$ \\
\hline FSU & FSU & Bla & 61.7 & 120.7 & 120.7 & FSU & Bro & 12.0 & 140.6 & 140.6 \\
\hline World & Total & All & 700.1 & 1242.9 & 1143.7 & & & & & \\
\hline
\end{tabular}

${ }^{\mathrm{a}}$ Ant $=$ Anthracite, $\mathrm{Bit}=$ Bituminous, $\mathrm{Sub}=$ Sub-bituminous, $\mathrm{Lig}=$ Lignite, $\mathrm{Bla}=\mathrm{Black}$, Bro $=$ Brown, Unk $=$ Unknown, $\mathrm{BSB}=$ Bituminous/Sub-bituminous, $\mathrm{SBi}=$ Semi Bituminous

${ }^{\mathrm{b}}$ Hubbert linearisation method

${ }^{\mathrm{c}}$ Reserves plus Cumulative production, Reserves from WEC 2007 [5], unless stated otherwise

${ }^{\mathrm{d}}$ Best Guess

${ }^{\mathrm{e}}$ From [25]

${ }^{\mathrm{f}}$ Differences between $\mathrm{HL}$ and $\mathrm{R}+\mathrm{C}$ might be due to possibly different classifications of the coal

g [26]

${ }^{\mathrm{h}}$ A Guess of $10 \%$ of $\mathrm{R}+\mathrm{C}$ reserves from [26]

${ }^{\mathrm{i}} \mathrm{HL}$ failed to produce an estimate used $\mathrm{R}+\mathrm{C}$ instead

${ }^{\mathrm{j}}$ Reserves estimated of $\mathrm{R}+\mathrm{C}$ made in 1992, production since then removed

${ }^{\mathrm{k}}$ From [27]

${ }^{\ell}$ From [28]

${ }^{m}$ A guessed reserves of $15 \mathrm{Gt}$ for all Mongolia

n [29]

${ }^{\circ}$ Germany URR from HL, Polish from R+C 
Table B.2

The peak year estimates for various countries and types for the different scenarios

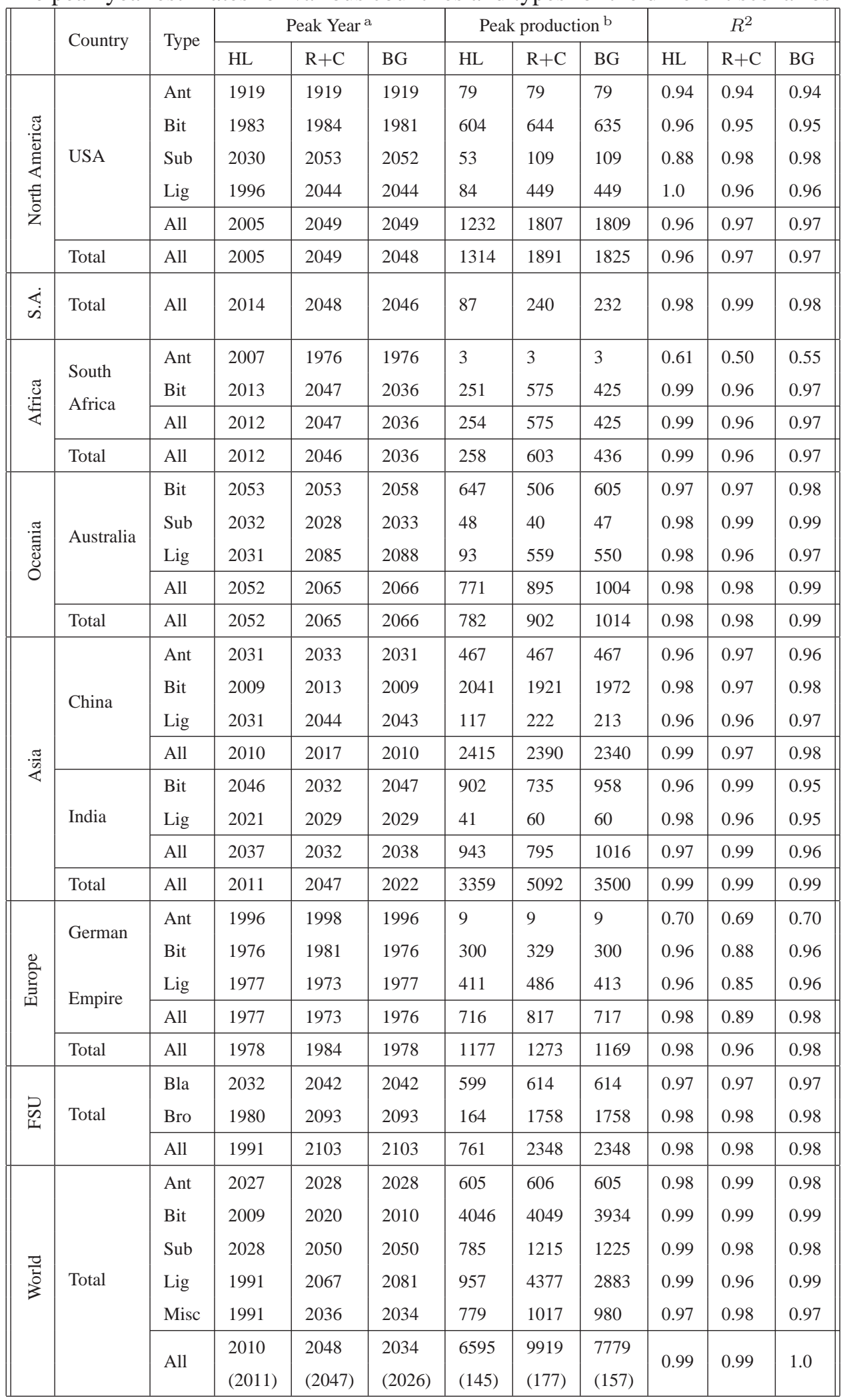

a If production has flat plateau type peak, then the peak year is the first year of the plateau, bracket number refers to peak year in an energy basis, otherwise mass basis

${ }^{\mathrm{b}} \mathrm{Bracked}$ value is production in $\mathrm{EJ} / \mathrm{y}$, otherwise $\mathrm{Mt} / \mathrm{y}$ 


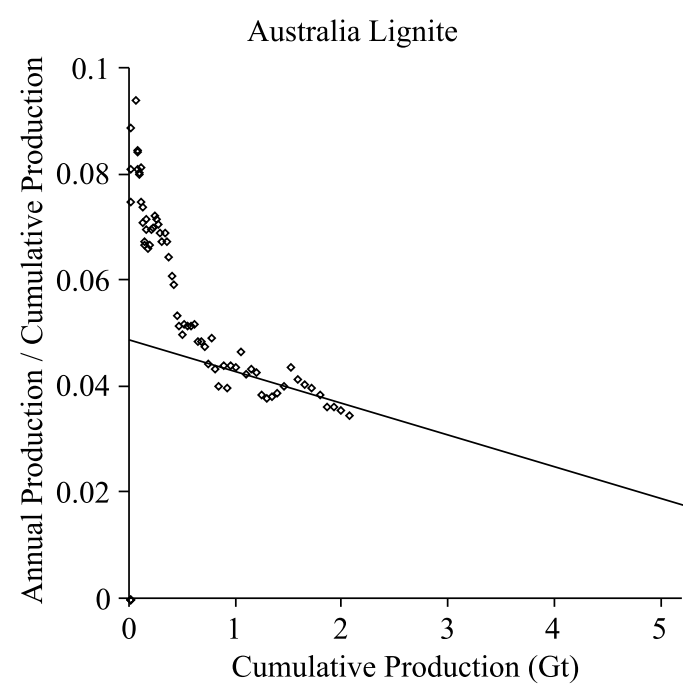

Fig. C.1. The Hubbert Linearisation trend for Australia Lignite

\section{Hubbert Linearisation URR determination}

The Hubbert Linearisation method [7] is shown graphically in figure C.1. The Linearisation leads to

$$
U R R=\frac{-b}{m}
$$

where $b$ is the intercept and $m$ is the slope of the linear fit. From Figure C. 1 and equation C.1, a linear fit to the data produces an estimate for the URR. Table C.1 lists the data range used to obtain the URR's, as well as the regression analysis $\left(r^{2}\right.$ values).

The Hubbert Linearisation method was not used for the following cases:

(1) Where production has ceased. The URR is taken as the total historic production.

(2) Where production has not commenced. THe URR was assumed to be zero.

(3) Where the slope of the Hubbert Linearisation trend was positive, see Table B.1 
Table C.1

The constants used to estimates the Hubbert Linearisation URR

\begin{tabular}{|c|c|c|c|c|c|c|c|c|c|c|}
\hline & Country & Type & Start year & Stop year & $R^{2}$ & Country & Type & Start year & Stop year & $R^{2}$ \\
\hline \multirow{4}{*}{ 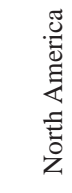 } & & Bit & 1987 & 2006 & 0.88 & \multirow{4}{*}{ USA } & Ant & 1973 & 2006 & 0.62 \\
\hline & Canada & Sub & 1989 & 2006 & 0.97 & & Bit & 1966 & 2006 & 0.87 \\
\hline & & Lig & 1992 & 2006 & 0.87 & & Sub & 2003 & 2006 & 0.32 \\
\hline & Mexico & Bit & 1996 & 2006 & 0.90 & & Lig & 2001 & 2006 & 0.89 \\
\hline \multirow{4}{*}{ 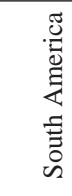 } & Argentina & Bit & 1973 & 2006 & 0.90 & Chile & Lig & 1988 & 2006 & 0.81 \\
\hline & \multirow{2}{*}{ Brazil } & Bit & 1952 & 2006 & 0.75 & Columbia & Bit & 1987 & 2006 & 0.38 \\
\hline & & Lig & 1968 & 2006 & 0.54 & Peru & Ant & 1981 & 2006 & 0.83 \\
\hline & Chile & Bit & 2005 & 2006 & 1.0 & Venezuela & Bit & 1998 & 2006 & 0.96 \\
\hline \multirow{7}{*}{ 莺 } & Botswana & Bit & 1991 & 2006 & 0.87 & South Africa & Bit & 1991 & 2006 & 0.88 \\
\hline & Egypt & Bit & 2002 & 2006 & 0.90 & Swaziland & Bla & 2004 & 2006 & 0.77 \\
\hline & Malawi & Sub & 1993 & 2006 & 0.50 & Tanzania & Bit & 2004 & 2006 & 0.99 \\
\hline & Mozambique & Bit & 2002 & 2006 & 0.79 & Zaire & Bit & 1961 & 2006 & 0.49 \\
\hline & Niger & Bit & 1992 & 2006 & 0.90 & Zambia & Bit & 1983 & 2006 & 0.84 \\
\hline & Nigeria & Sub & 1973 & 2006 & 0.86 & \multirow{2}{*}{ Zimbabwe } & \multirow{2}{*}{ Bit } & \multirow{2}{*}{1987} & \multirow{2}{*}{1999} & \multirow{2}{*}{0.87} \\
\hline & South Africa & Ant & 2005 & 2006 & 1.0 & & & & & \\
\hline \multirow{3}{*}{ 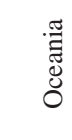 } & \multirow{3}{*}{ Australia } & Bit & 2003 & 2006 & 0.70 & \multirow{3}{*}{ N.Z. } & $\mathrm{Bit}^{\mathrm{a}}$ & 1987 & 2006 & 0.07 \\
\hline & & Sub & 1994 & 2006 & 0.81 & & Sub & 2003 & 2006 & 0.01 \\
\hline & & Lig & 1983 & 2006 & 0.53 & & Lig & 1962 & 2006 & 0.05 \\
\hline \multirow{11}{*}{$\frac{\pi}{4}$} & Afghanistan & Bit & 1979 & 2006 & 0.76 & \multirow{2}{*}{$\begin{array}{l}\text { Korean } \\
\text { Peninsula }\end{array}$} & Ant & 1976 & 2006 & 0.97 \\
\hline & Bangladesh & Bit & 2003 & 2006 & 0.30 & & Lig & 1976 & 2006 & 0.95 \\
\hline & Bhutan & Bit & 2005 & 2006 & 1.0 & Laos & Bit & 2003 & 2006 & 0.97 \\
\hline & \multirow{3}{*}{ China } & Ant & 1980 & 1997 & 0.30 & Malaysia & $\mathrm{Sub}^{\mathrm{a}}$ & 1992 & 2006 & 0.13 \\
\hline & & $\mathrm{Bit}^{\mathrm{b}}$ & 1971 & 2006 & 0.45 & \multirow{2}{*}{ Mongolia } & Bit & 1997 & 2006 & 0.14 \\
\hline & & Lig & 1998 & 2006 & 0.06 & & Lig & 2005 & 2006 & 1.0 \\
\hline & \multirow{2}{*}{ India } & Bit & 1995 & 2006 & 0.17 & Nepal & Sub & 2001 & 2006 & 0.83 \\
\hline & & Lig & 1999 & 2005 & 0.63 & Pakistan & Bro & 1995 & 2006 & 0.79 \\
\hline & Indonesia & Bit & 1994 & 2006 & 0.81 & Philippines & BSB & 2005 & 2006 & 1.0 \\
\hline & Iran & Bit & 1990 & 2006 & 0.58 & \multirow{2}{*}{ Thailand } & \multirow{2}{*}{ Lig } & \multirow{2}{*}{2003} & \multirow{2}{*}{2006} & \multirow{2}{*}{0.58} \\
\hline & Japan & Bit & 1986 & 2006 & 0.97 & & & & & \\
\hline & Albania & Lig & 1994 & 2006 & 0.10 & & Bit & 1994 & 2006 & 0.88 \\
\hline & AustroHungarian & Bit & 1995 & 2006 & 0.97 & Romania & Sub & 1989 & 2006 & 0.33 \\
\hline & Empire & Bro & 1990 & 2006 & 0.90 & & Lig & 1990 & 2006 & 0.69 \\
\hline & Bulaaria & Bit & 2002 & 2006 & 0.93 & & Ant & 1998 & 2006 & 0.96 \\
\hline & & Lig & 1990 & 2006 & 0.93 & Spain & BSB & 1997 & 2006 & 0.98 \\
\hline$\stackrel{\varrho}{\exists}$ & & Ant & 1997 & 2006 & 0.97 & & Lig & 1996 & 2006 & 0.86 \\
\hline & & Bit & 1981 & 2006 & 0.95 & The & $\mathrm{Bit}^{\mathrm{a}}$ & 2003 & 2006 & 0.48 \\
\hline & & Lig & 1968 & 2006 & 0.89 & & Lig & 1988 & 2006 & 0.89 \\
\hline & Greece & Lig & 1997 & 2006 & 0.97 & UK & Bit & 1993 & 2006 & 0.94 \\
\hline & Italy & Bro & 1994 & 2006 & 0.57 & Yugoslavia & Bit & 1986 & 2006 & 0.97 \\
\hline & Norway & Bit & 2003 & 2006 & 0.55 & & Bro & 2002 & 2006 & 0.81 \\
\hline FSU & FSU & Bla & 1983 & 1990 & 0.65 & FSU & Bro & 1995 & 2006 & 0.80 \\
\hline
\end{tabular}

${ }^{a} t_{0}$ was not the start year, but was 1973 for New Zealand bituminous, 1986 for Malaysian sub-bituminous and 1999 for Turkey bituminous

b The numbers refer to the HL applied to combined Chinese data, and the HL URR estimate for Chinese anthracite and lignite was removed, to obtain the bituminous URR value. 


\section{References}

[1] BP 2008 Statistical Review of World Energy, June 2008, BP website: http://www.bp.com/statisticalreview (8/10/2008)

[2] Hubbert M. K., Exponential Growth as a Transient Phenomenon in Human History. World Wildlife Fund's Conference, The Fragile Earth: Towards Strategies for Survival, San Francisco, 1976.

[3] Laherrere J., Oil and gas: what future? Groningen Annual Energy Convention 2006. http://www.oilcrisis.com/Laherrere/groningen.pdf (24/09/08)

[4] Zittel W., Schindler J., Coal: Resources and Future Production, Energy Watch Group, Paper No. 1/07, 2007. http://www.energywatchgroup.org/fileadmin/global/pdf/EWG_Report_Coal_10-072007ms.pdf $(24 / 09 / 08)$

[5] World Energy Council, 2007 Survey of Energy Resources, 2007

[6] Ion D. C., Availability of World Energy Resources, 1975, Graham \& Trotman Ltd

[7] Rutledge D., Hubbert's Peak, The Coal Question, and Climate Change, October 2007: http://rutledge.caltech.edu/ (2/10/08)

[8] Thielemann T., Schmidt S., Gerling J. P., Lignite and hard coal: Energy suppliers for world needs until the year 2100 - An outlook. International Journal of Coal Geology $2007 ; 72(1-14)$

[9] Kavalov, B., Peteves S. D., The Future of Coal. The Institute for Energy (IFE), prepared for European Commission Joint Research Centre EUR 22744 EN 2007. http://ie.jrc.ec.europa.eu/publications/scientific_publications/2007/EUR22744EN.pdf $(24 / 09 / 08)$

[10] Minerals U.K. World Mineral Statistics: Years 1913 to 2006. 
[11] Mitchell B. R., European Historical Statistics: 1750-1975, Second revised edition, 1981, The Macmillan Press.

[12] Mitchell B. R., International Historical Statistics: Africa and Asia, 1982, New York University Press.

[13] Mitchell B. R., International Historical Statistics: The Americas and Australasia, 1983, Gale Research Company

[14] Australian Bureau of Statistics: Yearbooks - 1908-2008. Australian Bureau of Statistics website:

http://www.abs.gov.au (8/10/08)

[15] Canadian Mineral Industry - Historical Information, Canadian Minerals Yearbooks 1944-1999, Canadian Mineral Statistics 1886-1956, Natural Resources Canada website

http://www.nrcan.gc.ca/mms/cmy/info-hist_e.htm

[16] Ouptut of Saleable Coal in the Principal Districts of Great Britain and Ireland and the Total Selling Value at Pit, Durham Mining Museum website http://www.dmm.org.uk/stats/toutput.htm (8/10/08)

[17] Pollard S., A New Estimate of British Coal Production, 1750-1850, The Economic History Review, 33(2), pg 212-235, 1980

[18] Milici R. C., The Coalprod Database: Historical Production Data for the Major CoalProducing Regions of the Conterminous United States U.S.G.S Open File Report 97447

[19] International Coal Production Tables, EIA website: http://www.eia.doe.gov/emeu/international/coalproduction.html (8/10/2008)

[20] World Coal Production, CoalPortal website: http://www.coalportal.com/production_trade_data.cfm?data_type=Production (8/10/2008) 
[21] The Brunei Coal Mine, The Daily Brunei Resources, Sunday June 11th 2006, The Daily Brunei Resources website: http://bruneiresources.blogspot.com/2006/06/brunei-coal-mine.html (8/10/2008)

[22] Mohr S., and Evans G., Demand-Supply Interaction on Future Mining Resource Production: The Coal Model, CSRP'08 Conference, 18-19th November 2008.

[23] Brandt A. R., Testing Hubbert, Energy Policy, 35(5), pg 3074-3088, 2007.

[24] R. Bonskowski, W. D. Watson, F. Freme, Coal Production in the United States - An Historical Overview, EIA website http://www.eia.doe.gov/cneaf/coal/page/coal_production_review.pdf (12/11/08)

[25] Baruya P. S. et al., Coal Online, Coal Resources, IEA Clean Coal Centre, 2003. http://www.coalonline.net/site/coalonline/content/home (8/10/08)

[26] E.I.A., Country Analysis Briefs, Bangladesh, July 2006, http://www.eia.doe.gov/cabs/Bangladesh/Coal.html (9/10/08)

[27] E.I.A. Coal reserves, EIA website: http://www.eia.doe.gov/emeu/international/contents.html (9/10/08)

[28] Mongolia: Business Opportunities for 2005, Special Advertising Section, Fortune Magazine September 19th, 2005, http://www.timeinc.net/fortune/services/sections/fortune/intl/media/2005_09mongolia.pdf $(9 / 20 / 08)$

[29] Vietnam Ministry of Foreign Affairs, Vietnam, Japan discuss minerals policies, Other news, 4th December 2007, http://www.mofa.gov.vn/en/nr040807104143/nr040807105039/ns071204093549 $(9 / 10 / 08)$ 